Original Research Paper

\title{
Sosialisasi Bahaya Penyebaran Paham Radikalisme Melalui Literasi Media Online Di Pondok Pesantren Unwanul Falah NW Paok Lombok, Lombok Timur Nusa Tenggara Barat
}

\author{
Muh. Zubair ${ }^{1 *}$, Bagdawansyah Alqadri1, Fitriah Artina', Ahmad Fauzan ${ }^{1}$ \\ ${ }^{\text {I} P r o g r a m ~ S t u d i ~ P e n d i d i k a n ~ P a n c a s i l a ~ d a n ~ K e w a r g a n e g a r a a n, ~ F a k u l t a s ~ K e g u r u a n ~ d a n ~ I l m u ~ P e n d i d i k a n, ~ U n i v e r s i t a s ~ M a t a r a m, ~}$ \\ Mataram, Indonesia;
}

https://doi.org/10.29303/jpmpi.v3i2.1107

Sitasi: Zubair, M., Alqadari, B., Artina, F \& Fauzan, A. (2021). Sosialisasi Bahaya Penyebaran Paham Radikalisme Melalui Literasi Media Online Di Pondok Pesantren Unwanul Falah NW Paok Lombok, Lombok Timur Nusa Tenggara Barat. Jurnal Pengabdian Magister Pendidikan IPA 4(4)

\section{Article history}

Received: 10 Oktober 2021

Revised: 30 Oktober 2021

Accepted: 17 November 2021

*Corresponding Author: Muh.

Zubair, Program Studi

Pendidikan Pancasila dan

Kewarganegaraan, Fakultas

Keguruan dan Ilmu Pendidikan,

Universitas Mataram, Mataram,

Indonesia;

Email: zubairfkip@gmail.com
Abstract: Sosialisasi tentang bahaya penyebaran paham radikalisme melalui media literasi online adalah salah satu variable kunci dalam memberikan pengetahuan dan pemahaman, serta keterampilan kepada para santri untuk mampu menyaring berbagai informasi yang beredar di media sosial. Pada analisis kondisi makro bangsa Indonesia saat ini terjadi penguatan intoleransi dan konservatisme. Pesantren dalam pandangan masyarakat dikenal sebagai lembaga pendidikan yang bersifat tradisional yang bertujuan untuk memahami, menghayati, dan mengamalkan ajaran Islam dalam kehidupan masyarakat sehari-hari, namun demikian belakangan ini pondok pesantren diisukan erat kaitannya dengan maraknya tindakan radikalisme. Secara umum hal tersebut disebabkan oleh pertama, peningkatan intensitas politisasi agama sejalan dengan tahun politik elektoral, khususnya Pilkada serentak gelombang ketiga pada Juni 2018 lalu, kedua, peningkatan intoleransi pada level individu dan kelompok warga, ketiga, kompleksitas persoalan pasal penodaan agama. Keempat, problem digital literacy dalam instrumentasi media sosial dan dunia maya oleh warganet. Kelima, kebangkitan kelompok-kelompok kontra narasi radikalisme, ekstremisme kekerasan, terorisme, dan anti-Pancasila. maka dari itu pengabdian ini akan melakukan sosialisasi tentang bahaya penyebaran paham radikalisme melalui media literasi online di Pondok Pesantren Unwanul Falah NW Pao` Lombok. Bedasarkan berbagai kajian masalah yang dihadapi, maka internalisasi pemahaman tentang bahaya paham radikalisme dalam kegiatan sosialisasi bahaya penyebaran paham radikalisme melalui literasi online di pondok pesantren Unwanul Falah NW, sehingga para santri memiliki literasi digital online untuk menangkal paham radikalisme. Kegiatan sosialisasi ini memberikan manfaat sbeagai berikut: (1) Membekali pengetahuan para santri dengan materi tentang bahaya paham radikalisme dan (2) memberikan keterampilan kepada para santri mengenai pemanfaatan teknologi dengan bijak (digital literasi online) agara bisa menangkal penyebaran paham radikalisme. Alur Pendekatan Kegiatan program dan alur prosedur program mulai dari kegiatan observasi sampai kegiatan berkelanjut.

Keywords: Literasi; Bahaya; Penyebaran; Radikalisme. 


\section{Pendahuluan}

Pada analisis kondisi makro bangsa Indonesia saat ini terjadi penguatan intoleransi dan konservatisme, Ada tiga isu yang selalu disebarkan oleh kelompok radikal, pertama adalah intoleransi, anti-Pancasila, dan anti NKRI (Damai, 2020). Menurut Khamid, (2016) radikalisme memiliki rencana jangka panjang antara lain menimbulkan perubahan dramatis dalam pemerintahan, revolusi, mengganti ideologi suatu negara dengan ideologi kelompoknya, mempengaruhi kebijakan pembuat keputusan baik dalam lingkup lokal, nasional, regional atau internasional. Dalam upaya memberikan pengaruhnya kepada masyarakat, kelompok radikal menggunakan media sosial online sebagai sarana untuk menyebarkan narasi radikal. Menurut Sulfikar, (2019) media sosial dan jejaring online sebagai saluran komunikasi massa adalah pilihan yang sangat strategis bagi kelompokkelompok radikal, karena pesan yang disebarluaskan melalui media sosial sumbernya lebih sulit terdeteksi, memiliki potensi dampak yang luas, dan biaya yang lebih murah. Lebih lanjut dikemukakan bahwa media sosial oleh kelompokkelompok radikal ini membuktikan kemampuan mereka untuk menggantikan peran media arus utama sebagai saluran untuk penyebaran pesanpesan yang tidak dapat dimiliki kelompokkelompok ini. Mereka menggunakan internet sebagai katalis untuk kekerasan dan alat propaganda yang efektif untuk mendapatkan dukungan dan simpatisan (Sari, 2017).

Pengalaman bagaimana internet telah digunakan dan memainkan peran penting dalam propaganda radikalisme adalah sebuah kenyataan, (Hui, 2010) dalam penelitiannya mengemukakan data dari peneliti Khaled al-Faram tahun 2018 menyatakan bahwa ada 5.600 situs web yang menyebarkan ideologi yang dipengaruhi Al Qaeda di seluruh dunia, dan jumlahnya meningkat 900 web setiap tahun. Di Indonesia Noordin M Top, tokoh Jamaah Islamiyah (JI) yang mengorganisir sejumlah aksi bom besar di Indonesia, diyakini telah memerintahkan pembuatan website berisi cara-cara untuk menyerang orang asing di Indonesia, kemudian dalam tulisan (Sumardiana, 2017) mengemukakan bahwa ada jaringan ISIS sebagai salah satu organisasi gerakan teroris yang mampu memanfaatkan media sosial sebagai media propaganda sekaligus rekuritmen keanggotaan.
Selain itu munculnya fenomena gerakan negara ilusi seperti "Keraton Sejagat", "Sunda Empire", dan "Negara Rakyat Nusantara" yang mengunggah aktivitasnya di media sosial dan menginginkan negara Indonesia segera dibubarkan, Selain itu, yang tidak kalah menghebohkan, kemunculan video anak-anakIndonesia yang tengah dilatih perang oleh ISIS yang tersebar di YouTube padaMaret 2014. Serta kasus lain, ketika kelompok Rizky Gunawan berhasilmengumpulkan dana sebesar Rp5 milyar dari hasil meretas sejumlah situskomersil untuk membiayai pelatihan militer teroris di Poso.

Meluasnya panggung propaganda yang dilakukan teroris melalui dunia maya jugadidukung oleh pernyataan mantan kepalaBadan Intelijen Nasional (BIN), Sutiyoso:

"Saat ini, pergerakan kelompok terorisme di Indonesia cenderung lebih mengoptimalkan akses jejaring social media untuk menyebarkan ideologi, propaganda dan rekrutmennya. Hal ini, mengingat ketatnya fungsi monitoring dan pengamanan wilayah yang dilakukan seluruh penyelenggara sistem keamanan nasional, serta sistem intelijen negara. Sehingga, secara geografis, potensi pergerakan ancaman terorisme semakin sempit, namun propaganda ideologinya secara potensial lebih luas karena memanfaatkan akses mediasosial" (Kertopati, 2015: 2).

Berdasarkan pada survei penetrasi pengguna internet 2019-2020 yang dirilis oleh Asosiasi Penyelenggara Jasa Internet Indonesia (APJII) menyebutkan bahwa total pengguna internet di Indonesia yakni 196.71 juta jiwa $(73,7 \%)$ dari total 266.91 juta jiwa penduduk Indonesia, dengan durasi penggunaan internet yakni 8 jam lebih ke atas dalam sehari dengan tujuan penggunaan internet adalah akses media sosial (APJII, 2020). Menurut Sulfikar, (2019) informasi yang disebarluaskan oleh siapa pun telah menembus ruang-ruang pribadi jutaan orang di Indonesia. Artinya, dapat dikatakan bahwa pengguna media sosial di Indonesia adalah pasar yang sangat potensial bagi kelompok radikal yang menggunakan media sosial sebagai sarana propaganda.

Pesantren dalam pandangan masyarakat dikenal sebagai lembaga pendidikan yang bersifat tradisional yang bertujuan untuk memahami, menghayati, danmengamalkan ajaran Islam dalam kehidupan masyarakat sehari-hari, namun demikian belakangan ini pondok pesantren diisukan erat 
kaitannya dengan maraknya tindakan radikalisme (Muin, dkk, 2007). Secara umum hal tersebut disebabkan oleh pertama, peningkatan intensitas politisasi agama sejalan dengan tahun politik elektoral, khususnya Pilkada serentak gelombang ketiga pada Juni 2018 lalu, kedua, peningkatan intoleransi pada level individu dan kelompok warga, ketiga, kompleksitas persoalan pasal penodaan agama. Keempat, problem digital illiteracy dalam instrumentasi media sosial dan dunia maya oleh warganet.Kelima, kebangkitan kelompok-kelompok kontra narasi radikalisme, ekstremisme kekerasan, terorisme, dan antiPancasila.Kondisi ini menuntut Indonesia mewaspadai, mencegah, melawan radikalisme yang dapat memecah belah dan mengganggu keselamatan negara-bangsa.

Pembinaan toleransi adalah salah satu variabel kunci dalam membina dan mewujudkan kerukunan dan inklusi sosial, serta membangun negara Pancasila yang bersendikan kemerdekaan beragama sebagai diafirmasi oleh Sila Pertama Pancasila dan dijamin oleh UUD Negara Republik Indonesia tahun 1945, Pasal 29 Ayat (2). Sekolah sebagai heterogenitas sosial kultural yang tinggi merupakan kantung masyarakat (social enclaves) dituntut untuk memainkan peran positif sebagai representasi negara dalam wajah yang lebih spesifik dan particular.

Alvara Research Center pada tahun 2016 terkait pandangan keagamaan umat Islam Indonesia. Survei dilakukan terhadap 1085 responden yang tersebar di 15 propinsi di Indonesia, hasilnya adalah ada 17,8 persen mahasiswa dan 18,4 persen pelajar yang setuju khilafah sebagai bentuk negara ideal sebuah negara. Paparan konservatisme dan radikalisme di kalangan milenial tidak lepas dari konsumsi internet yang sangat tinggi. Menurut data Alvara, sebanyak 83,4 persen dari penduduk berusia 17-25 tahun di Indonesia mengakses internet, sebanyak 23 persen di antaranya tergolong pecandu internet karena mengakses internet lebih dari tujuh jam sehari (Alvara Research Center, n.d.).Data dari UNICEF memperlihatkan jumlah anak-anak dan remajapengguna internet yang lebih besar lagi, yakni mencapai lebih dari 30 jutapengguna (Gayatri et al., 2015). Lebih lanjut menurut hasil penelitiantersebut, anak-anak dan remaja ini paling banyak menggunakan internetuntuk tiga tujuan utama yakni pertama untuk mencari informasisehubungan dengan tugas sekolah dan bahan belajar, kedua untukpertemanan, dan ketiga untuk hiburan.Livingstone (2008: 12) menyatakan bahwa salah satu penyebab perilaku internet berisiko adalah keterbatasan kemampuan literasi internet remaja.

Menurut Khamid, (2016) pemanfaatan teknologi medsos yang digunakan secara baik akan berakibat baik pula bagi kehidupan manusia, walaupun masih ada saja yang menyimpang dan menggunakan medsos untuk hal-hal yang kurang bermanfaat dan bahkan untuk hal-hal negatif seperti untuk memecah belah ummat. Melalui medsos youtube dibuat video-video yang saling menghina dan merendahkan antar kelompok, itu merupakan contoh penyalahgunaan yang justru akan berakibat buruk pada manusia.

Perkembangan teknologi yang makin canggih, trend penggunaan media sosial telah dimanfaatkan oleh kelompok radikal untuk menebar pahamnya yang bisa mengancam idiologi Pancasila sebagai negara kesatuan RI.Perlu ada usaha bersama dalam rangka membentengi masyarakat dari pengaruh paham radikal untuk menjaga keutuhan bangsa secara preventif.Peran aktif sebagai benteng idiologi sangat efektif terhadap virus idiologi paham gerakan radikalisme yang tidak hanya merongrong dan mencoreng ajaran Islam, tetapi juga bisa mengancam persatuan dan kesatuan bangsa dan negara.Sangat penting bagi institusi pendidikan untuk membekali siswasiswa nya dengan wawasan kebangsaan, keindonesiaan serta keislaman yang moderat, terbuka dan damai dan bagaimana menggunakan teknologi secara bijak.

Hal ini penting karena generasi penerus bangsa ada ditangan para siswa ini. Dengan moment reformasi demokrasi, para pengusung ide radikal terus gencar mengembangkan pahamnya, maka dari itu pengabdian ini akan melakukan sosialisasi tentang bahaya penyebaran paham radikalisme melalui media literasi online di Pondok Pesantren Unwanul Falah NW Pao` Lombok.

\section{Metode}

1) Waktu dan tempat program ini dilakukan di sekolah MA UNWANUL FALAH NW PAOK LOMBOK di Jl.TGH Ahmad Abdul Gani No.1 Paok Lombok, Kecamatan Suralaga, Selong Lombok Timur, Nusa Tenggara Barat. 
2) Alur Pendekatan Kegiatan sosialisasi bahaya penyebaran paham radikalisme melalui media literasi online di pondok pesantren Unwanul Falah NW, yakni:

a. Pendekatan Partisipatif

Dilakukan secara koordinatif, melibatkan Tim Pelaksana dengan Mitra MA Unwanul Falah NW. Forum komunikasi dan koordinasi ini sebagai wadah strategis untuk membahas persoalan administratif, teknis, pendanaan, secara terbuka dan demokratis untuk menemukan solusinya bagi pihak-pihak yang dilibatkan.

b. Pendekatan Konseptual

Dilakukan dengan pola pembinaan sikap dan mental dan pengetahuan siswa di wilayah mitra. Harapannya siswa di wilayah mitra memiliki pengetahuan tentang radikalisme sehingga upaya untuk mewujudkan atau menangkal radikalisme dikalangan pelajar/siswa dapat dilakukan dengan efektif sebagai bentuk upaya preventif (pencegahan).

c. Pendekatan Teori

Dilakukan melalui kegiatan tatap muka dan diskusi.

\section{d. Pendekatan Reflektif}

Dilakukan dengan evaluasi kegiatan selanjutnya dilakukan refleksi dan keberlanjutan dalam bentuk monitoring dan pendampingan, baik terprogram maupun insidental guna menjaga kualitas hasil kegiatan serta meningkatkan kemitraan.

3) Langkah-langkah sistematis yang dilakukan pada kegiatan ini mengikuti prosedur dalam delapan tahapan berikut:

a. Observasi

Dilakukan dengan melakukan survei dan wawancara untuk pengumpulan data permasalahan radikalisme serta konflik sosial pada wilayah kerja mitra. Sasaran adalah siswa.Tujuan metode ini adalah untuk mengumpulkan data awal berupa fakta di lapangan untuk mendapat pemecahannya, seperti tentang pandangan siswa tentang nasionalisme radikalisme dan ekstrimisme. b. Koordinasi

Sesudah ditemukannya fakta-fakta dan permasalahan tentang pandangan radikalisme dan ekstrimisme siswa, selanjutnya dilakukan koordinasi dengan pimpinan lembaga serta pengurus organisasi kesiswaan di wilayah kerja mitra, pejuang perdamaian, duta perdamaian dan perwakilan siswa untuk memilih aspek permasalahan yang prioritas untuk mendapat pemecahannya.

c. Sosialisasi Program

Selanjutnya dilakukan pembentukan Panitia Pelaksana yang terdiri dari Tim dosen, tim siswa, mitra, serta relawan yang memiliki kepedulian terhadap isu-isu perdamaian secara umum. Kerja Tim Pelaksana selanjutnya adalah melakukan sosialisasi tentang program berupa pendidikan damai yang perlu diberikan kepada siswa, serta teknis pelaksanaanya. Pada forum ini diupayakan dilakukan secara demokratis dan partisipatif guna memperoleh hasil keputusan yang efektif.

d. Pelaksanaan

Setelah diperoleh kesepakatan tentang materi yang akan diberikan kepada peserta, segera dilakukan pelaksanaan program oleh Tim sesuai SOP.

e. Pelaporan

Sebagai wujud akuntabilitas dan transparansi baik dalam pengelolaan keuangan dan administrasi maka pelaporan segera dilakukan disertai bukti fisiknya.

\section{Hasil dan Pembahasan}

Pada kegiatan sosialisasi tim pengabdian melakukan evaluasi diri secara internal untuk melakukan identifikasi faktor-faktor yang menjadi pendukung dan penghambat. Pemetaan ini menjadi penting agar tim pengabdian dapat mengetahui secara tepat faktor yang turut menentukan keberhasilan kegiatan. 


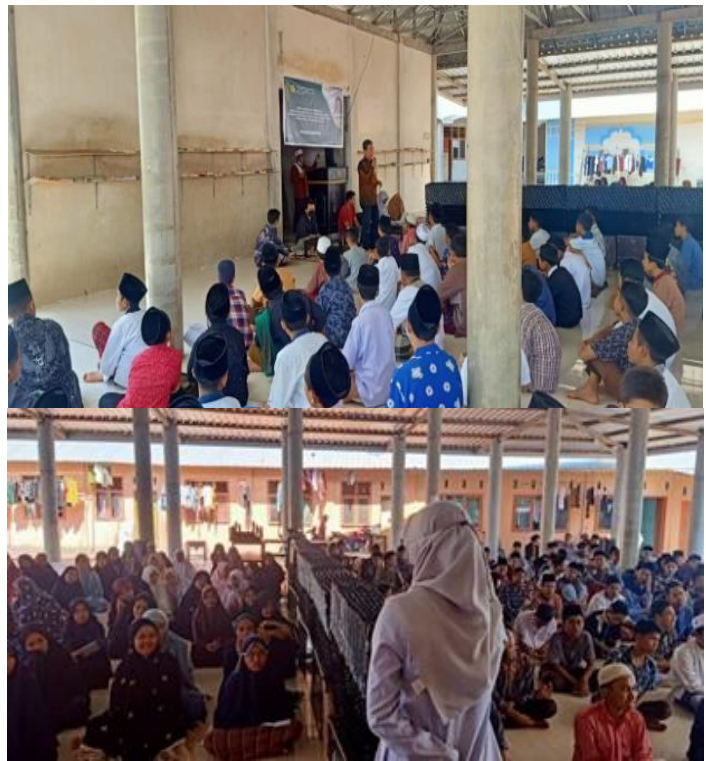

Gambar 1. Kegiatan Sosialisasi

\section{Faktor Pendukung}

Pada kegiatan sosialisasi tim pengabdian melakukan evaluasi diri secara internal untuk melakukan identifikasi faktor-faktor yang menjadi pendukung dan penghambat. Pemetaan ini menjadi penting agar tim pengabdian dapat mengetahui secara tepat faktor yang turut menentukan keberhasilan kegiatan.

1. Pembinaan toleransi adalah salah satu variabel kunci dalam membina dan mewujudkan kerukunan dan inklusi sosial, serta membangun negara Pancasila yang bersendikan kemerdekaan beragama sebagai diafirmasi oleh Sila Pertama Pancasila dan dijamin oleh UUD Negara Republik Indonesia tahun 1945, Pasal 29 Ayat (2). Sekolah sebagai heterogenitas sosial kultural yang tinggi merupakan kantung masyarakat (social enclaves) dituntut untuk memainkan peran positif sebagai representasi negara dalam wajah yang lebih spesifik dan partikular.

2. Sekolah merupakan lokus sekaligus institusi yang paling strategis dalam melakukan rekayasa sosial, dibandingkan dengan pranata sosial lainnya. Singkatnya, sektor pendidikan adalah medium yang menentukan suatu kondisi sosial masyarakat baik pada masa sekarang maupun di masa yang akan datang.

\section{Faktor Penghambat}

Persoalan pola pikir masyarakat khususnya masyarakat atau pemuda bahkan pondok pesantren yang berada di daerah pedesaan, sangat mudah untuk terpengaruh terhadap hal-hal atau opini yang dimanipulasi kemudian memiliki pengaruh atau tendensi agama yang selanjutnya dimanfaatkan oleh pihak-pihak tertentu ataupun kelompok-kelompok ekstrimis dengan tujuan untuk dapat menambah jumlah massa ataupun partisipan mereka. Temuan tersebut hanya menggambarkan satu soal dari kurang kondusifnya pembelajaran toleransi di lingkungan pendidikan.

\section{Hasil Kegiatan}

Meningkatnya pengetahuan dan pemahaman para siswa tentang radikalisme melalui kegiatan sosialisasi tentang bahaya penyebaran paham radikalisme melalui media literasi online, diuraikan dalam bentuk Hasil uji pada pre-test dan post-test terhadap peserta kegiatan mengenai Persepsi siswa terhadap radikalisme.

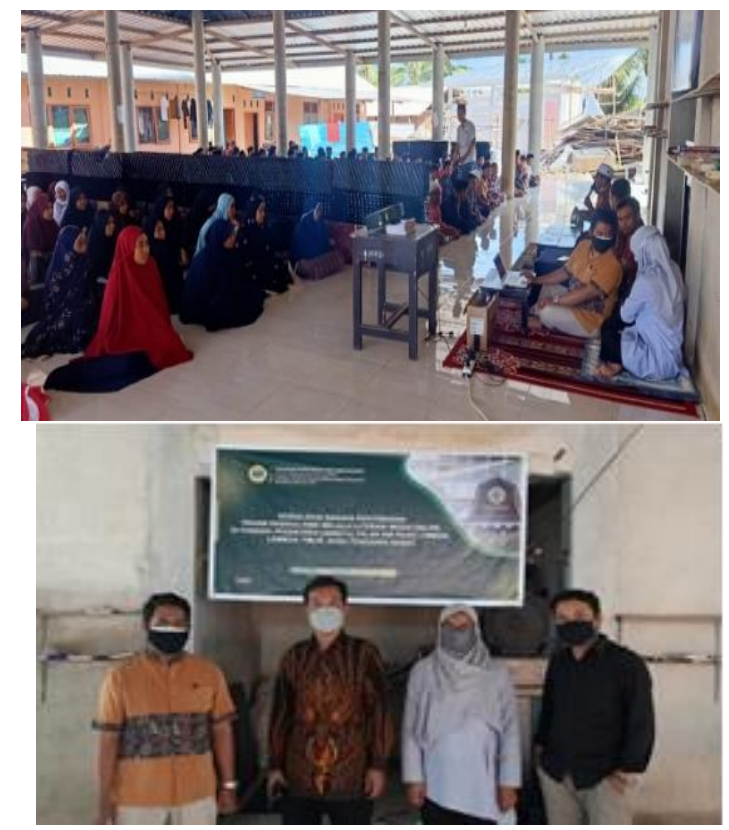

Gambar 2. Pemberian Materi Sosialisasi

Hasil uji menunjukan bahwa hasil post tes (28) ternyata lebih tinggi dari pada pre-test (12). Berdasarkan hasil uji ini nampak bahwa ada peningkatan pemahaman peserta terhadap definisi rasikalisme. Peserta memiliki pengetahuan yang lebih baik pada definisi radikalisme hal ini sangat 
penting mengingat terjadi miskonsepsi terkait dengan pengertian radikalisme.

- Saluran penyebaran radikalisme

Terdapat perubahan skor yang cukup signifikan terkait pemahaman peserta mengenai saluran penyebaran radikalisme. Semula skor pretest sebesar (9) dan setelah mengikuti kegiatan diperoleh hasil skor psot test sebesar (30). Perubahan pengetahuan terhadap saluran penyebaran radikalisme dapat membantu peserta mengidentifikasi pola penyebaran ide-ide radikal melalui pola dan sarana-sarana.

\section{- Tujuan Radikalisme}

Dari segi pemahaman mengenai tujuan radikalisme nampak juga mengalami perubahan, dilihat dari besarnya skor dari skor post-test atas pre-test. Terdapat peningkatan skor dari (10) menjadi (30). Para peserta menyadari pemahaman tujuan radikalisme menjadi penting untuk diketahui agar peserta mampu mengetahui dan memahami sikap yang bisa dikenali dari sikap dan paham radikal.

\section{- Dampak/Akibat radikalisme}

Pemahaman terkait dengan dampak radikalisme terjadi peningkatan skor menjadi (30) pada hasil post-test. Para peserta menyadari bahwa perlu memahami akibat atau dampak yang ditimbulkan dari radikalisme sehingga dapat dijadikan sebuah cuan distingsi untuk menghindari terlibat radikalisme.

\section{Kesimpulan}

Berdasarkan dari seluruh kegiatan pengabdian interfaith youth leadership dalam menangkal

1. Sekolah merupakan lokus sekaligus institusi yang paling strategis dalam melakukan rekayasa sosial, dibandingkan dengan pranata sosial lainnya. Singkatnya, sektor pendidikan adalah medium yang menentukan suatu kondisi sosial masyarakat baik pada masa sekarang maupun di masa yang akan datang.

2. Peserta memiliki pengetahuan yang lebih baik pada definisi radikalisme hal ini sangat penting mengingat terjadi miskonsepsi terkait dengan pengertian radikalisme.

3. Perubahan pengetahuan terhadap saluran penyebaran radikalisme dapat membantu peserta mengidentifikasi pola penyebaran ideide radikal melalui pola dan sarana-sarana.
4. Para peserta menyadari pemahaman tujuan radikalisme menjadi penting untuk diketahui agar peserta mampu mengetahui dan memahami sikap yang bisa dikenali dari sikap dan paham radikal.

5. Peserta menunjukkan respon positif, perhatian, dan mengikuti kegiatan Sosialisasi tentang bahaya penyebaran paham radikalisme melalui media literasi online sangat baik, peserta memberikan, mengajukan pertanyaan, pendapat, dan memberikan jawaban dari pertanyaan narasumber dengan baik, hal ini menunjukan bahwa siswa sebagai generasi muda memiliki respon sangat baik dalam upaya menangkal radikalisme.

\section{Daftar Pustaka}

Abd. Muin, dkk. (2007). Pendidikan Pesantren dan Potensi radikalisme. Jakarta: CV. Prasasti.

APJII. (2020). Laporan Survei Internet APJII 2019 2020. Asosiasi Penyelenggara Jasa Internet Indonesia, 2020, 1-146. https://apjii.or.id/survei

Damai, P. M. (2020). Teropong Potensi Radikalisme 2020. Jalan Damai (Majalah Pusat Media Damai BNPT), 58.

Gayatri, G., Rusadi, U., Meiningsih, S., Mahmudah, D., Sari, D., Kautsarina, N., \& Karman, N. (2015). Digital Citizenship Safety Among Children and Adolescents in Indonesia. Jurnal Penelitian Dan Pengembangan Komunikasi Dan Informatika, 6(1), 122672.

Hui, J. Y. (2010). The internet in Indonesia: Development and impact of radical websites. Studies in Conflict and Terrorism, 33(2), 171191. https://doi.org/10.1080/10576100903400605

Kertopati, S. (2015). Publik Perlu Kekebalan Sosial Agar Tidak Mudah Terpengaruh Propaganda Terorisme. Rakyat Merdeka.

Khamid, N. (2016). Bahaya Radikalisme terhadap NKRI. Millati: Journal of Islamic Studies and Humanities, 1(1), 123. https://doi.org/10.18326/mlt.v1i1.123-152

Livingstone, Sonia. (2008). Young People Media. London: Sage Publications [online], diakses pada 22 Februari 2021, tersedia pada http://eprints.lse.ac.uk/21177/1/Young_people_ne w_media_(LSERO).pdf

Sari, B. D. A. C. (2017). Media literasi dalam kontra propaganda radikalisme dan terorisme melalui 
media internet. Peperangan Asimetrik, 3(1), 1531.

Sulfikar, A. (2019). Swa-radikalisasi Melalui Media Sosial di Indonesia. Jurnal Jurnalisa, 4(1), 7690. https://doi.org/10.24252/jurnalisa.v4i1.5622

Sumardiana, B. (2017). efektivitas penanggulangan ancaman penyebaran paham ekstrim kanan yang memicu terorisme oleh POLRI dan BNPT RI. Seminar Nasional Hukum Universitas Negeri Semarang, 3(1), 109-128. 